The Euro at 22: economic crisis and political instability

Mariana Mortágua

Maio de 2021

WP n. ${ }^{\circ} 2021 / 04$

DOCUMENTO DE TRABALHO

WORKING PAPER

dinamia 'cet_iscte

Centro de Estudos sobre a Mudança Socioeconómica e o Território

\title{
isctee
}




\section{dinamia 'cet_iscte}

The Euro at 22: economic crisis and political instability Mariana Mortágua*

WP n. 0 2021/04

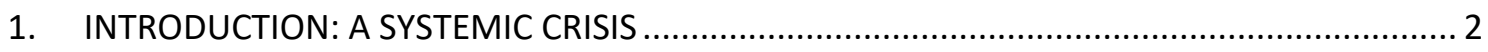

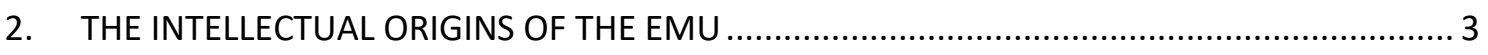

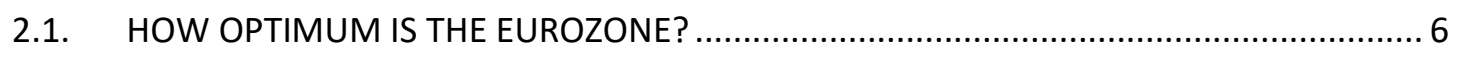

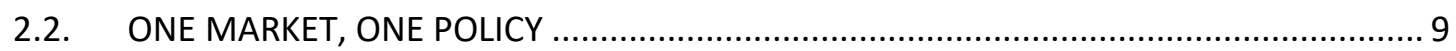

2.3. THE NEW MACROECONOMIC CONSENSUS MEETS THE LSE GROUP ......................... 11

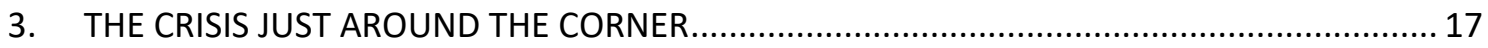

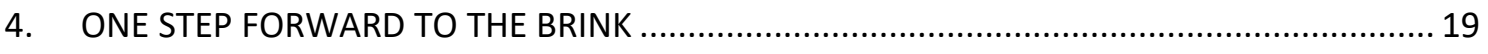

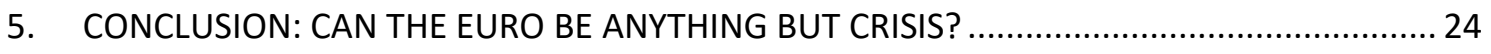

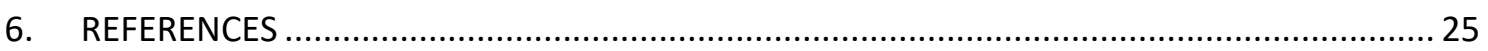




\title{
The Euro at 22: economic crisis and political instability
}

\begin{abstract}
This paper discusses the origins and institutional evolution of the European Monetary Union (EMU) in the light of two theoretical frameworks: the liberal federation proposed by Hayek and Robbins in the first half of the $20^{\text {th }}$ century and the still prevailing neoclassical macroeconomic consensus. It is argued that before existing as Euro, the common currency was already a neoliberal project, in the sense of an ideal space for elevating market rules to a unique and definitive form of social and economic order. This neoliberal construction was technically legitimized by a neoclassical economic theory founded on wrong epistemological principles, which prevented a correct understanding of the economic and social challenges faced by the Eurozone. The result is a crisis prone configuration that will keep endangering EMU's political and economic stability.
\end{abstract}

Keywords: Neoliberalism, European Integration, Economic and Monetary Union

\section{INTRODUCTION: A SYSTEMIC CRISIS}

Twenty-two years after the launch of the Euro, it is time for a retrospective analysis on the European Economic and Monetary Union (EMU). This paper discusses the theoretical and institutional evolution of the EMU until the aftermath of the Great Recession, with one question in mind: could these very institutions have produced a different outcome?

The political creation of the EMU, as well as its specific institutional design, have raised much interest both from academics and politicians. The official narrative presents it as the outcome of a benevolent project of peace and prosperity. In the words of Jacques Delors in 1989, since "you cannot fall in love with the single market", something else is needed (Delors, 1989). This story, crafted out of the need for self-legitimacy, conceals deep political contradictions in EMU's foundational motivations and serious flaws in its institutional design. ${ }^{1}$

\footnotetext{
${ }^{1}$ See Delanty (1995) for a critical analysis of the construction of the European identity and Zimmermann (2001) for a summary of the theoretical and historical context of the early European Monetary integration.
} 
Within economics literature, scholars working on the margins of heterodoxy have tried to understand the characteristics and defects of the common currency in the context of the main political, theoretical and ideological movements of its time. For instance, Buiter (1992), Buiter et al. (1993) and Arestis and Sawyer (2001) look into the institutional defects of EMUs initial framework, namely the deflationary bias of the Stability and growth Pact; Arestis and Sawyer (2013) study the monetary integration process in the framework of the prevailing neoclassic consensus; Dow (2016) analyses it from the point of view of the Theory of the Optimum Currency Areas; Young (2014) explores the scope of influence of the German ordoliberal traditions in the European institutional reforms; while Mitchell and Muysken (2006) look for the underpinning role of the neoliberal policies associated with the Washington Consensus.

The long process of European economic and monetary integration carries enough complexity to accommodate, even partially, all of these arguments. The European Union and, in particular, the EMU, like any other set of institutions, emerge from confluence of different geopolitical interests, predominantly in the Franco-German arch, and the dominant ideological and theoretical structures of the time.

This paper focuses on these structures seeking to go through the process of European economic and monetary integration in the light of the evolution of the neoliberal thinking and the neoclassical theoretical consensus to argue that, before existing as Euro, the common currency was already a neoliberal project: not under this label, or with this specific geographical configuration, but as an ideal space for elevating market rules to a unique and definitive form of social and economic order. This neoliberal construction was technically legitimized by a neoclassical economic theory founded on wrong epistemological principles, which prevented a correct understanding of the economic and social challenges faced by the Eurozone.

Keeping the European response to the Great Recession in mind, it is fair to question if the Euro was ever designed to respond to the needs of the working class or with the purpose of building fairer economies.

\section{THE INTELLECTUAL ORIGINS OF THE EMU}

The Great Depression that followed the crash of the New York Exchange in 1929 shook the theoretical and practical foundations hitherto in force. On the one hand, it paved the way for alternatives to the neoclassical tale of perfect markets; on the other, it called into question the pillars of the existing economic policy, starting with the gold standard and the globalized liberalization of the $19^{\text {th }}$ century. 
John Maynard Keynes was one of the most notable pessimists about the effectiveness of free markets and the advantages of free trade, as he saw in these factors the causes of the 1929 crisis. Recognizing, however, the need for international trade and payments, Keynes designed a system that aimed to allow different countries to participate in the international system while maintaining room for maneuver for protectionist and social policies. Without entering into an unnecessary level of detail, the proposal was to create a book-entry currency that would serve as a standard for international transactions and avoid the use of gold or another dominant currency, such as the dollar. This currency would be managed by a kind of world central bank, responsible for ensuring a shared adjustment between surplus and deficit countries. It would thus be possible to avoid the typical adjustment of the gold standard systems, where it is up to the deficit country to withstand all adjustment through economic recession and falling production prices (namely wages). The other elements of the proposal consisted of the introduction of capital controls, debt support mechanisms and fixed but adjustable exchange rate systems. ${ }^{2}$

Needless to say, the final version of the Bretton Woods agreement in 1944 fell far short of these sensible lows. Nevertheless, the debate that matters to understand the theoretical origins of the European Monetary Union lies nearby. While Keynes' proposals for the new world economic order were fighting for their ideological and theoretical claims, Friedrich Hayek and Lionel Robbins worked out much more radical plans from the London School of Economics (LSE). These contributions, which will be addressed next, can be found in Robbins book Economic Planning and International order, published in 1937 and in a set of Hayek's lectures, published in 1937 under the title Monetary Nationalism and International Stability that were closed followed by the publication of a chapter on The Economic Conditions for Interstate Federalism (1939). ${ }^{3}$

Hayek and Robbins' concern was to offer an alternative to the more protectionist trends coming from Cambridge, meant to allow the participation of the neoliberal hosts in the debate on the new international order. The international economic integration process was yet under dispute, and the argument coming out of the LSE group was that an international federation built on liberal ideals that guaranteed the recognition and enforcement of property rights, free trade and free functioning of markets, would be the ideal place to restrict government's action and impose a process of liberal globalization. After all, it is always a matter of institution building, the question is which institutions will deliver the desired outcome.

Competition was key in this new framework. Marx referred to competition as a coercive law imposed from abroad capable of disciplining individual capital and organizing the process of capitalist reproduction. Hayek and Robbins' proposal was based on the creation of a space where

\footnotetext{
${ }^{2}$ See Skidelsky (2005) for an account of Keynes ideas on globalization and international economic institutions.

${ }^{3}$ For a more detailed review of these contributions see Thomasberger (2015).
} 
this mechanism could exercise its disciplining power without interference. If protection policies could no longer be an option, competition in such an integrated economic space would require the acceptance of market demands on wages, prices, regulations, tax policy, etc.

Claus Thomasberger (2015) summarizes the necessary conditions for the construction of this neoliberal federation, according to the LSE group. The first would be the construction of a single market without restrictions on the movement of goods, capital, services and people. The resulting regime of competition between countries would ensure the organization of the economic and social system. Governments would then lose decision-making power over tax policies, labor rules and social protection measures. And what did not arise automatically should be imposed by the mutual recognition of the conditions of competition between different countries. Therefore, "even with respect to less thoroughgoing interference with economic life than the regulation of money and prices entails, the possibilities open to the individual states would be severely limited... As has been shown by experience in existing federations, even such legislation as the restriction of child labor or of working hours becomes difficult to carry out for the individual state. (Hayek, 1939). The second was monetary unification, with the transfer of powers to a supranational entity protected from interference by national government. The objective was to eliminate the negative effects of exchange rate, inflation or interest rate fluctuations on the normal functioning of markets and private investment. Unable to guarantee a currency that could fulfil these characteristics and, therefore, the neoliberal design, a regime of fixed exchange indexed to gold should prevail. This system would ensure that adjustments between countries were made by internal devaluation (through falling wages, unemployment and recession) and never by attributing losses to creditors. The third condition concerned the creation of a supranational political power to protect competition, private property and the functioning of the single market, and define the legal and institutional framework of monetary policies. National states would be left with the responsibility for the infrastructure and services necessary for the economy to function and to meet the basic needs of the population.

Thomasberger translates Hayek's final argument in the following way: "protection against market forces presupposes common traditions, value orientations, and a sense of community that may exist on a national level, but not within a larger union. Hence, it will be impossible to establish on a union level the protective measures that have to be given up within the single nations." (2015, p.193)

In short, to work, the market regime needs order, and that order is not compatible with the democratic aspirations of sovereign nation states. National governments are limited in their action by legal norms, but also by permanent pressure from external competition. At the supranational level, the existing rules but also disparities in values, traditions and priorities prevent the 
rebuilding of protection elements. The integration process is then reduced to the very removal of national barriers, protections and regulations, which remains the lowest common denominator amongst all.

The extent to which these and other contributions written by Hayek and Robbins between the 1930s and 1970s directly influenced, or only anticipated, the European construction process is a matter for debate. It can also be discussed if, alongside the liberal origins that inspired the Treaty of Rome - which first established the freedom of movement of people, goods, services and capital - lived a genuine political desire to harmonize and strengthen social mechanisms of protection.

In any case, it seems clear today that, as argued by Scharpf (2009), the European Union developed through a negative integration process. Countries with different political backgrounds, in particular those with strong welfare states, protective labor rules and traditions of economic intervention were compelled to dismantle their own institutions without and equivalent counterpart at the European level. As Hayek and Robbins predicted, the resultant structure of such neoliberal federation proved to be immune to the will of sovereign countries, regardless of the different political configurations in the European Parliament.

In the following sections it will be showed how these premonitions came to fruition within an institutional framework that, in almost every respect, was built pari passu with developments in neoclassical theory and neoliberalism.

\subsection{HOW OPTIMUM IS THE EUROZONE?}

The theory of optimum currency areas (TOCA) is based on an original contribution by Robert Mundell in 1961. The article, A Theory of Optimum Currency Areas, discusses balance of payments problems that emerge in the context of fixed exchange rate regimes. However, in the search for a solution to the "international system imbalance" (p.657), Mundell rejected at all the advantages of a system of flexible exchange rates - which allows the correction of imbalances through an external rather than internal adjustment, (usually devaluation) - advocated by opponents of the gold standard system that existed in the $19^{\text {th }}$ Century until the Great Depression. The argument develops around the conditions that make it preferable for a country or region to adopt either regime. According to Mundell, a system of flexible exchange rates is only preferable if it can be proved that the national currency can ensure the stability of the international system. Thus, this "flexible exchange rate stabilization argument is valid only if it is based on regional currency zones" ( $\mathrm{p} .663)$, within which different regions or countries must be united by a fixed exchange rate or the same currency. For a set of regions or countries to be considered an optimal 
currency zone, labor and capital factors must be movable so that, in the good way of the neoclassical general equilibrium theory, adjustments occur automatically.

Mundell describes several imaginary worlds to reach the same conclusion: without factor mobility, a negative asymmetric shock will always bring inflation and/or unemployment, seen as equally negative. Under flexible exchange rates, the devaluation of the currency of the tradedeficit country transfers the adjustment to the surplus country in the form of inflation. Under fixed exchange rates, the loss-making country is not allowed to devalue, so adjustment must take place in the form of unemployment and falling GDP. There are also, of course, intermediate possibilities for cooperation which allow the burden of adjustment to be shared between both regions, whether they be a monetary union or a set of independent currencies. Surplus countries could accept some inflation that would prevent unemployment in deficit countries, or there could be a common central bank that would guarantee the issuance of international means of payment. Still, issuing new currency to fight the recession would bring inflation to surplus countries, something undesirable, according to Mundell.

In theory, the unemployment/inflation binomial can only be avoided if different economies are regionally organized into optimal currency zones. In this case, unemployment and falling output would be automatically compensated for by the migration of capital and workers to the surplus zone, until prices in the deficit area were attractive enough to resume private investment. Even if we assumed perfect factor mobility, it is clear that this optimal adjustment would have devastating economic, social and territorial effects on the deficit area. But these are not the concerns of neoclassical economics, focused on finding the mechanisms that guarantee the free balance of markets.

Mundell regains some realism by recalling that "in the real world, of course, currencies are mainly an expression of national sovereignty, so that actual currency reorganization would be feasible only if it were accompanied by profound political changes" as in Western Europe (Mundell, 1961, p.661). However, although he recognizes the intrinsic relationship between currency and national sovereignty and, thus, the difficulties associated with a loss of sovereignty, Mundell sums up European monetary integration with an empirical problem: whether or not Western Europe enjoys the mobility of factors that allow it to be characterized as an optimal currency zone? ${ }^{4}$

From its foundation, based on the work of Mundell (1961) but also McKinnon (1963) and Kenen (1969), the TOCA has undergone substantial changes that, in a way, reflected the European

\footnotetext{
${ }^{4}$ See Goodhart (1998) for a critique of the optimum currency area theory, and its application to the EMU, for its misconception of money. Goodhart argues that Mundell's theory takes a purely technical view in which currency emerges as an instrument solely intended to minimize market transaction costs. In fact, money is a complex social phenomenon that shapes debt and power relations and is intrinsically related to the legitimacy of a sovereign state.
} 
monetary integration debate. After a first phase, during the 1970s, devoted to the discussion of properties that could constitute an optimal currency zone, the theory was relegated to the background. In part, the disinterest it was subjected to reflected the obvious difficulties in finding in this abstract model the answers to the very concrete challenges faced by the leading European leaders. However, during the 1980s and 1990s, the TOCA regained some of its old role, now focusing on operationalizing the identified properties.

The new approach "recognizes the shortcomings of theories based on a single face of the economy and tries to evaluate costs and benefits of participating in a currency union from the point of view of the self-interest of a particular region of country. According to this approach, the optimum currency area is defined at the margin by the balance between the costs and benefits of having a common currency" (Ishiyama, 1975, p.345).

Thus, for each country, the decision to participate in a monetary union should start from an analysis of its costs - namely the loss of monetary autonomy and the effects of adjustment in the event of asymmetric shocks in terms of unemployment and output - in relation to benefits elimination of exchange rate risk, better conditions for trade and investment, higher levels of financial integration and market access, greater macroeconomic stability.

Despite these changes and its influence on the European debate, the authors of the One Market, One Money report, published in 1992 by the European Commission Directorate-General for Economic and Financial Affairs, argued that the TOCA was not yet a ready-to-use theory. The absence of a unified theory of monetary zones led to this report being accompanied by extensive theoretical and empirical production which, among other things, exposed the main inconsistencies between the theoretical principles underlying the TOCA, heir to the old theories of general equilibrium, and the new neoclassical consensus that emerged in the late 1990s.

Thus, the Report reinforces the neoclassical dislike of inflation, calling for the need for a price moderation policy at European level, and devalues the role of other OCA properties in analyzing the greater benefits of a monetary union. In its initial versions, the TOCA admitted that both foreign exchange and monetary policy represented important instruments of economic adjustment, hence the costs associated with its abdication. These elements became now less important as economic theory moved to a new paradigm based on the idea that price moderation will suffice to bring the economy to equilibrium. Monetary policy has thus ceased to promote employment and economic growth and has lost its role as an adjustment mechanism.

The new TOCA inherits these criticisms, focusing its attention on three topics. Firstly, the ability of national economies to achieve and maintain moderate levels of inflation as an essential condition for integrating a monetary union. As inflation largely depends on future price expectations, exchange rate devaluation is likely to result in inflationary pressures. Thus, 
exchange rate policy also lost weight as an adjustment mechanism. On the other hand, membership of a monetary union can give credibility to governments goals of maintaining low levels of inflation. Second, the conditions that guarantee the necessary wage and price flexibility to absorb asymmetric shocks. Third, the importance of financial integration as a mechanism for mitigating external shocks in the monetary union, based on the argument that "a country suffering from unexpected output shock can reduce its costs if it holds claims on another country not affected by the shock. A corollary of this argues that the similarity of shocks is not a pre-requisite for sharing a single currency if all members of the currency are finally integrated and hold claims on each other's output" (Mongelli, 2002, p.6).

The last element in the development of the TOCA, developed by De Grauwe and Mongelli (2005), known as the endogeneity hypothesis, adds the final self-justifying argument in favor of an European single currency. According to this hypothesis, the benefits of joining a monetary union far outweigh the elimination of currency risk. Other long-term benefits could come from greater financial and economic integration, and from building stronger relationships between member countries that could ultimately lead to an ex-post synchronization of economic cycles. In other words, the debate on preconditions for membership can be summarized by nominal criteria - such as inflation - since structural convergence will emerge as a consequence of monetary integration.

This was the vision that inspired the various institutional steps towards integration, including the Maastricht Treaty in 1992, the cornerstone of the European monetary building that would come into force in 1999. In the debate on the conditions that would allow several countries to share one currency, prevailed the idea that economic convergence would be the automatic product of the convergence between interest rates, inflation rates and exchange rates. It was a victory of the socalled "monetarists" over the "economists", who warned of the need for prior structural convergence criteria such as the unemployment rate or productive structures (Coffey and Presley 1971).

\subsection{ONE MARKET, ONE POLICY}

Convergence was thus seen as the automatic result of integration, as trade and free capital movements would bring the different economic structures closer together, promoting an efficient allocation of resources at European level. Hence the initial effort to liberalize and deregulate goods and capital markets.

It was on the basis of this neoclassical framework that the accumulation of current account imbalances in the euro area was completely neglected. Until the crisis, current deficits in the peripheral economies of the Eurozone were seen as the natural result of the convergence of 
financial flows to these countries in search of better rates of return (Blanchard \& Giavazzi, 2002). In the future, once the automatic adjustment process had been completed, the rates of return were expected to equalize and countries in deficit would use the proceeds of past investment to return to equilibrium.

The (very credible) assumption that these deficits were being fuelled by uncontrolled flows of financial capital seeking returns in underproductive areas such as construction, real estate or rentier sectors was not considered. Nor could it be, in a world of perfect markets with efficient resource allocation.

This is not to say that the hypothesis of external or internal shocks affecting different economies in different ways has not been considered. The literature on this subject is immense. But as the summary published in the European Parliament's Report, Adjustment to Asymmetric Shocks (1998) demonstrates, all realistic warnings were ignored on the basis of an irrational optimism about the ability of automatic adjustment mechanisms.

The report identifies two types of adjustment mechanisms, namely market-based mechanisms and institutional mechanisms. Market-based mechanisms were subdivided into flexible pricing - the ability of an economy to devalue wages to overcome a crisis; and flexible quantities - the mobility of capital and workers through emigration as a way to deal with unemployment. The report is clear in its recommendations: easing labor laws, reducing unemployment support, deregulating goods, financial, banking and capital markets.

Institutional mechanisms, in turn, boiled down to the possibility of budget transfers between countries and to countries in crisis. Nevertheless, the widespread belief was that such mechanisms would postpone the necessary structural reforms, giving national governments the possibility of avoiding the painful adjustment by unemployment and wage devaluation. Moreover, it was feared that the idea of a European safety net would foster profligate behaviors by national governments, so budgetary transfers (including structural funds) were limited and the possibility of financial bailout was banned from the European framework. According to the editors of Prospects and Challenges for the Euro (Begg et al.,1998), "the implementation of an EMU transfer mechanism to help regions absorb asymmetric shocks might reduce rather than strengthen the monetary union's ability to cope with such shocks".

Member states' fiscal autonomy has yet been restricted in other ways. The Maastricht Treaty, signed in 1992, which established the goals for nominal convergence before the introduction of the Euro in 1999, limited budget deficits up to $3 \%$ and public debt ratios up to $60 \%$. In 1997, the Stability and Growth Pact, enforced the rules established in the Maastricht Treaty by the creation of new mechanisms of fiscal monitoring by the European Commission and the Council of Ministers. These mechanisms consisted of a "preventive arm" - yearly policy recommendations - 
, and a "corrective arm"- corrective measures following the declaration of Excessive Deficit Procedure.

Embedded in these rules, as in most European institutions, one can find the suspicion of government and democratic institutions that dominated mainstream economics after the intellectual takeover by the Chicago School. After the Great Recession, this view was deepened under the influence of the liberal ideas developed by a group of economists from the Bocconi University (Helgadóttir, 2016).

To these views we owe the creation and deepening of the so-called independent institutions, whose aim is to ensure the proper functioning of markets: property rights, competition policies, prohibition of state aid and, most important of all, an independent monetary policy focused on inflation. This is not to say, however, that the erection of the European institutional building was not subject to particular influences, such as the German monetary tradition, found today in the statutes and practical functioning of the European System of Central Banks (Bibow, 2012). Beyond these influences lied also more pragmatic arguments, based on the need to guarantee the Euro, a currency cut off from the power of a sovereign, the credibility granted by international financial markets. To this end, it had to be ensured that the new currency maintained a long-term commitment to its value that could not be threatened by expansionary monetary policies or by the irresponsibility of governments looking for popular approval.

\subsection{THE NEW MACROECONOMIC CONSENSUS MEETS THE LSE GROUP}

In the late 1970s, the oil crises and the ensuing stagflation contributed to shattering post-war interventionist policies such as Bretton Woods. This was the academic and political context in which Milton Friedman's ideas gained ground, and this was also the time to think about monetary integration in Europe.

Friedman's main argument in the Monetary History of the USA (Friedman and Shwartz, 1963) was that in the short term, injecting more money into the economy can have a positive effect on the unemployment and output. In the long run, however, the economy tends towards equilibrium, a "natural rate of unemployment". If the money supply continues to increase, the result will not

be a reduction in unemployment but more inflation. Hence the monetary known monetary formula: the central bank must be the main institution, and monetary policy the main instrument of economic policy. The goal is to control the supply of money at every moment according to an objective rule and fiscal policy, subject to the irrational wills of governments, only gets in the way. 
When the ECB was first established, its mandate was mainly directed towards the control of the monetary base growth to ensure macroeconomic stability in the eurozone. But Friedman's monetarism lasted only as long as reality allowed it to last. Just as the European builders ignored the importance of the link between the State and the currency, monetarists neglected the fact that money is an endogenous variable, that can be created ex-nihilo by the financial system. Money supply cannot simply be controlled by any theoretical rule set by any central bank.

Monetarism gave way to another consensus, known as the new macroeconomic consensus, or the new neo-Keynesian synthesis, which seek to integrate core elements from the neoclassical theoretical body - optimization, rational expectations, centrality of monetary policy - with developments coming from neo-Keynesian approaches, namely the idea of imperfect markets.

It is in the light of this new consensus that one can read the European institutional design that prevailed before the Great Recession, based on three main pillars: efficient markets, inflation control as the main instrument of macroeconomic policy, and supply-side reforms.

The efficient markets hypothesis was translated into the idea that the free movements of good, services and capital flows are natural mechanisms of long-term convergence and stability. The Cecchini Report (1988), that evaluated the expected gains from the 1992 program for unifying the European Community's internal market, strongly advocated for the elimination of all barriers to free trade and capital movements.

Therefore, trade liberalization was followed by the liberalization of national capital accounts and by a large set of financial reforms aiming the construction of a Single Market, following the Single European Act of 1992.5 Bongini (2003) identifies two groups of measures in the financial liberalization model adopted in the EU. The first was the coordination of bank legislation through a series of Directives aiming the completing of the single market for the banking industry. These included the definition of banking services, the overall standardization of the German model of universal banking across Member States, the liberalization of financial and banking activities with the encouragement of privatizations, and the substitution of the previous quantitative restrictions to banking activity (interest rate ceilings, quotas on credit expansion and administrative limitations on new banks and branches) for a supervision system based on prudential rules. The second group regarded the opening of banking and capital markets to foreign competition. The most important legislative piece in this direction was the Second Banking Coordination Directive (89/646/EEC) that introduced the "single passport". The concept refers to the freedom of establishment and operation to member state banks. The Financial Services Action Plan,

\footnotetext{
${ }^{5}$ See Story and Walter (1997) and McCann (2010) for a discussion of the origins and process of financial integration in the EU and EMU.
} 
presented in 1999 by the Commission, meant the harmonization of financial services markets across the EU.

EU member States had very different starting positions in what regards the level of openness, regulation and ownership (private or public) of their own financial systems. Therefore, especially for bank-based countries with highly regulated state-owned financial institutions, the political decision of joining the economic and monetary integration process in the 1980's came with radical impositions towards financial liberalization and deregulations. ${ }^{6}$

The risks of such structural transformations for macroeconomic and financial stability dissipated under the widespread belief, translated, for example, in the several editions of De Grauwe's Economics of Monetary Union, that:

"An integrated stock market works as an insurance system. The risk of a negative shock in one country is shared by all countries. As a result, the impact of the negative output shock on the income of the residents of that country is mitigated." (de Grauwe, 2014, p.19)

Monetary policy, understood in the context of the EMU, as the stabilizing instrument par excellence, was an important piece in the overall framework of liberalization and deregulation. Money supply controls have been replaced by an inflation rule (up to 2\%), achieved through interest rate manipulation, and the ESCB was conceived to assume the role of independent guarantor of this long-term strategy. Fiscal policy was reneged to a secondary and subservient role.

In the Stability and Growth Pact (SGP), signed in 1997, Member States agreed to abide by the medium-term budgetary positions close to balance or in surplus, as new enforcing rules and guidelines were established. ${ }^{7}$ In its preventive arm, the SGP established the mandatory submission of an annual stability program providing the medium-term objective for the budgetary position as well as the adjustment path towards it, including the description and quantification of the main budgetary measures. Stability programs were to be examined and monitored in their implementation by the Council, that would recommend adjustment measures in the event of a foreseeable excessive deficit. SGP corrective arm determined the conditions under which a government deficit over the objective could be admitted (in the case of an annual fall of real GDP

\footnotetext{
${ }^{6}$ Examples of such countries are Portugal, France, Italy, Spain, Greece, Belgium, Ireland, Norway and Iceland (McCann, 2010).

${ }^{7}$ The initial version of the Stability and Growth Pact consisted of the Council Regulation (EC) No 1466/97 of 7 July 1997 on the strengthening of the surveillance of budgetary positions and the surveillance and coordination of economic policies, the Council Regulation (EC) No 1467/97 of 7 July 1997 on speeding up and clarifying the implementation of the excessive deficit procedure and the Resolution of the European Council of 17 June 1997 on the Stability and Growth Pact.
} 
of at least 2\%), the deadlines for the adoption of correction measures and the imposition of sanctions.

The European Commission's vision was clear in this regard in the early 2000's:

"Achieving and sustaining sound positions in public finances is essential to raise output and employment in Europe. Low public debt and deficits help maintain low interest rates, facilitate the task of monetary authorities in keeping inflation under control and create a stable environment which fosters investment and growth (...) The Maastricht Treaty clearly recognises the need for enhanced fiscal discipline in economic and monetary union (EMU) to avoid overburdening the single monetary authority and prevent fiscal crises which would have negative consequences for other countries. Moreover, the loss of the exchange rate instrument implies the need to create room for fiscal policy to tackle adverse economic shocks and smooth the business cycle. The Stability and Growth Pact (SGP) is the concrete manifestation of the shared need for fiscal discipline." (COM, 2000, p.1)

Further on, the Commission takes up the argument:

"Such a strong emphasis on fiscal prudence and stability in the Maastricht Treaty derived from the belief that the deterioration of public finances was an important cause behind the poor economic performance of many EU countries since the early 1970s. The subsequent decades taught Europe a salutary lesson of how economic prosperity cannot be sustained in an unstable economic policy environment. Inappropriate fiscal policies frequently overburdened monetary policy leading to high interest rates. On the supply-side, generous welfare systems contributed to structural rigidities in EU economies and fuelled inappropriate wage behaviour. The net effect was a negative impact on business expectations and on investment, thus contributing to a slower rise in actual and potential output." (ibid. p.9)

This last argument put forward by the Commission leads us to the third vertex of this European construction: supply-side economics. The new consensus framework conceives the level of economic activity as fluctuating around a natural unemployment rate. If the authorities insist on tackling unemployment with demand-side policies the result with be a rise in market prices. The only way to intervene in the economy is to change the structural conditions of supply, translated in the concept of potential output, as argued by the Commission.

The central role played by "competition policy" at the European level emerges then from the combination between two key neoclassic ideas. On the one side, the transformative powers of supply side measures; on the other, the efficiency of free markets, as defended in the Cecchini Report. This view was translated into the agenda of the Directorate-General for Competition of the European Commission (DGComp), focused on the enforcement of competition rules through 
the elimination of all type of administrative barriers, including state aid and, in particular, on the promotion of market liberalization.

Sectoral directives aimed at creating a single "competitive" market in previously protected areas, often in markets dominated by state-owned monopolies, imposed the liberalization of several sectors, such as telecommunications, transports, electricity and gas and postal services. Although the method and extent of national regulations varied across sectors and countries, in most cases liberalization came with the privatization of large state-owned companies. As argued by Clifton et al. (2003), "structural pressures, in particular those that liberalized certain sectors in preparation for European market integration, were important factors in explaining the privatization of public enterprises. Liberalizing directives acted as catalysts in the privatization of key sectors in the EU14 (...)”(pp.751-752).

Privatizations were also fostered by the fiscal constraints established in the SGP, that forced reductions in the subsidization of public enterprises and promoted its sale as a way to reduce public debt, and by the EU's state aid rules, that prohibit most forms of public intervention in liberalized markets. ${ }^{8}$

A different but related aspect of this agenda concerned EU policy efforts to extend liberalization into national labor regulations, by claiming that employment protective legislation created damaging rigidities in labor markets and in the economy. After a first deregulation wave, in the 1980s and 1990s, aimed at extending fixed term contracts, the European rhetoric, confirmed in the Lisbon agenda, was built around the concept of "flexicurity" (Heyes, 2011). Flexicurity meant a shift from the protection of workers to the protection of employers' need for a flexible workforce, with the adoption of supply-side measures aimed at deregulating contractual arrangements. This shift placed the center of employment policies on workers' employability, that should be supported by "lifelong learning strategies", "effective labour market policies", and modern social protection, capable of providing "incentives and support for job transitions" (Council conclusion on the common principles of flexicurity, 2007). In practice, the increasing levels of "flexibility" in new contracts was not balanced with new levels of protection. On the contrary, out-of-work benefit entitlements (as other forms of protective mechanisms) suffered substantial reductions under this new ideological framework, also due to the greater pressure put by the European fiscal rules on national budgets. In the Treaty of Lisbon (2007) as well as in the Europe 2020 strategy (2010) the evidence of a growing dualization in labor markets, as precarity

\footnotetext{
${ }^{8}$ The EU State aid regime is defined in general terms in the Articles 107 to 109 of the Treaty on the Functioning of the European Union (TFEU). Article 107 (1) of the TFEU defines State aid as "[...] any aid granted by a Member State or through state resources in any form whatsoever which distorts, or threatens to distort, competition by favoring certain undertakings or the production of certain goods shall, insofar as it affects trade between Member States, be incompatible with the internal market".
} 
rose on those groups most affected by deregulation (young and/or temporary workers), led the Commission to ask national countries to "implement their national pathways for flexicurity" (EC, 2010, p. 17).

The Great Recession exposed the real face of flexicurity, as countries were forced to increase flexibility while cutting on security programs, raising unemployment, social inequality and precarity (Hayes, 2013 and Tangian, 2010).

In sum, this necessarily concise exposition of EUs main economic choices intended to support the claim that the main goals of liberal internationalism have been fulfilled. What was not achieved by a new body of institutions, laws, directives and norms, was imposed by the continuing need to compete in the internal market, or to resist the assessment of financial markets.

It is certainly true that neither European politicians are neoclassical theorists, nor are the European institutions the faithful application of a single theoretical body. If not for another reason, because there is no unified theory of monetary integration. The building of the European Union and the European Monetary Union is the product of geopolitical strategies and powers, institutional traditions and powerful lobbying activities. What is being argued is that all these elements converged into the institutionalization of the neoliberal consensus, based on the new NeoKeynesian synthesis, which enshrines the radical liberal project designed by Hayek and Robbins in the 1930's.

The single-market and the competition-enhancing policies of the European Commission have set an agenda for liberalization and privatization of the main economic sectors. As predicted, national economy's "external competitiveness" and the need to attract foreign investment have served as a narrative to justify the dismantling of employment protection legislation and the pre-existing tax regimes, which are now called upon to offer better tax conditions to large companies and multinational economic groups. State aid rules prevent national governments from carrying out any industrial policy measures, including the ownership of strategic companies.

The European monetary space ended with the "monetary nationalism" that concerned Robbins so much. National central banks have been replaced by a monetary superstructure whose sole purpose is to secure the value of the new currency, which is not gold, but is artificially designed to behave as such. Once separated from democratic power, the new currency is itself a disciplining mechanism. Its value depends on financial markets and their assessment of ECB policies and their commitment to that goal. The Euro is thus a private currency (Parguez, 1999).

Having lost control of monetary and exchange rate policies, states cannot devalue their currency, inject money to promote demand, or finance themselves with the central bank. Without access to Community-level adjustment or financing mechanisms, there is nothing left for these countries 
but submit themselves to the scrutiny of financial markets for credit and to accept painful internal deflation adjustment processes. Democracy was captured by the private financial sector, which behaves like States' shareholder.

Even without complete political unification, which has been progressing and retreating, notably with the attempt to create a European Constitution, the existing integration has created the institutions that ensure the self-reinforcement of the neoliberal project:

"The LSE conditions do not allow for the will of the People, for a democratic government or for a parliament of the union, which diverge from liberal principles. The conditions presuppose that the supranational political authority of the union accepts the limits set by the principles of economic liberalism and, wherever necessary, possesses the power to prevail against the national governments." (Thomasberger, 2015, p.193)

The union is, after all, a straitjacket.

\section{THE CRISIS JUST AROUND THE CORNER}

Over these 20 years, if the European Union did not find an alternative direction, it was certainly not for lack of warning. Outside the neoclassical cycles, appeals from academics and politicians abounded, aware of the theoretical inconsistencies, democratic shortcomings and institutional failings of the process of European integration, in particular as regards the construction of the single currency. ${ }^{9}$

At stake was not only the detrimental effects of economic competition between countries with different productive structures, degrees of specialization and modernization, but, above all, the destabilizing potential of abrupt financial and capital liberalization in a context of low interest rates. It was anticipated then that, contrary to efficient resource allocation, the most likely outcome of this process would be the concentration of the banking sector and the accumulation of macroeconomic imbalances (Chick and Dow, 1997). In the absence of control mechanisms, these substantial flows would not create jobs or economic development, but the accumulation of financial debt and inflationary pressures in specific sectors, such as construction, real estate, stock markets and financial assets in general.

ECB's distorted view obsessed with only one type of inflation - average euro area price developments - and one type of causes - wage increases or government deficits - led it to ignore these risks. In a way, the difficulty is understandable, since the interest rate appropriate for

\footnotetext{
${ }^{9}$ Recall some of the references aforementioned, for example Arestis and Sawyer (2001), Arestis and Sawyer (2013), Goodhart (1998), Parguez (1999) and also Bibow (2003).
} 
Germany in the 1990s was far below what was necessary to cool the effects of financial deregulation in Portugal. On the other hand, the fall in interest rates that could have helped peripheral countries soon after the crisis was halted by the inflation bogeyman's fears, which, as the future would show, was the last of Europe' concerns.

The experience of the EU and EMU over the last twenty years did not cease to prove its old criticisms right: i) it is a mistake to focus monetary policy on controlling inflation and, therefore, ii) hardly the same monetary policy can be applied to several economies; iii) especially without being complemented by other compensatory instruments, such as national fiscal policy or an intraCommunity transfer system (Kaldor, 1970).

This perspective makes it easier to understand the accumulation of structural weaknesses in the euro area that have manifested themselves in the form of current account imbalances, excessive public and private indebtedness, speculative bubbles in certain sectors and, above all, a disappointing performance in terms of employment. None of this is surprising if we think of the Euro as a currency built to derive its value from the legitimacy conferred by markets, rather than its ability to create wealth or jobs.

Despite all indications to the contrary, in June 2008, the European Commission declared the Euro as a "resounding success" that "secured macroeconomic stability and boosted cross-border trade, financial integration and investment". However, it was also recognized that "so far it has fallen short of some initial expectations. Output and particularly productivity growth have been below those of other developed economies and concerns about the fairness of income and wealth distribution have grown" (COM, 2008). Nevertheless, the success was "resounding".

By September 2008 the Lehman Brothers would fail, wiping out what was left of the optimism that characterized the Euro-enthusiasts since the first discussions about optimal currency zones. The financial crisis caught the ECB off guard as it staunchly watched the speculative movement over sovereign debts, the asphyxiation of national banking systems, and the transformation of current account imbalances into a payment crisis.

In theory, imports from another member country can always be financed as they are paid for in euros by credit created by the banking system. But for this process to take place without disruptions, there must be a central bank willing to provide unlimited liquidity to banks. Without such liquidity, banks will cut credit, triggering a process of internal devaluation through bankruptcies, unemployment and falling wages, that will forcefully reduce imports. Another way to soften this process is to secure funding to support government spending. The injection of money through the banking system and the state will produce the inflation needed to relieve the prisoner of its debt and aid recovery by minimizing impacts on employment and output. It is due to these secular functions that central banks are called lenders of last resort (Goodhart, 1999). 
None of these instruments was available during the Great Recession that followed the Lehman crisis, nor was the restructuring of public debts. However, it should be recalled that the priority given to maintaining the value of the Euro currency required international payments to proceed without major disruptions. Hence, Member States alone endured the effects of economic recession while public debts were under a wave of speculative attacks. This was the context that allowed the imposition of austerity plans, supported by the financial system and coordinated by the ECB, the European Commission and the European and international institutions.

The whole intellectual path of European construction indicates that the perverse response to the crisis was not the result of carelessness, ignorance or even innocent reliance on the wrong economic theory. Disaster is the disciplining mechanism at work.

\section{ONE STEP FORWARD TO THE BRINK}

"The Treaty assigns to the European Central Bank (ECB) the single objective of price stability. The ECB has provided a clear definition of this objective, as annual inflation in the euro area of below $2 \%$, but close to $2 \%$, over the medium term.

Since its establishment in the summer of 1998 the ECB has worked hard to fulfil this objective. The results are very clear. We have seen 12 years of low inflation and low interest rates. The average annual inflation rate in the euro area has been $1.97 \%$. It is the best result in terms of price stability for any large euro area country over the past 50 years.

After one of the most difficult years for our still young common currency, it is time to turn the page. It is time for each and every Member State to live up to its responsibilities. And it is time to strengthen the code of conduct for national governments, notably the Stability and Growth Pact, of which I will not hesitate to say that Theo Waigel is the founding father.

We know that for several years fiscal policies in some countries have breached both the letter and the spirit of the Pact. The problems that hit some European bond markets last year were a visible and tangible testimony of fiscal misconduct.

The watering-down of the Pact in 2004 and 2005 by Europe's largest economies was a quieter event, but it was no less grave. In that period, Member States chose to change the rules rather than their policies (...)" (Trichet, 2011).

The crisis forced the ECB to act as lender of last resort to the financial system in order to keep the payments systems working and to protect the common currency. The quantitative easing program solved the liquidity problem but did not avoid a liquidity trap with further consequences 
to financial stability (Summers, 2014; Krugman, 2014). Furthermore, and contrary to what could be expected given its independence mandate, the ECB made these operations dependent on markets' assessment of sovereigns' credit ratings and on the adoption of further austerity measures.

The European Commission, the European Central Bank and the Eurogroup have thus interpreted the crisis from their own ideological and theoretical framework. One can now sing it by heart: if there is a crisis, it is because (i) State intervention has distorted automatic adjustment mechanisms; and ii) the factors - capital and labor - were not sufficiently "mobile". ${ }^{10}$ In practice, this means, budgetary controls, economic deregulation and financial integration.

The first and second goals were achieved, first of all, through the austerity programs designed to limit social support mechanisms, to cut public spending, privatize strategic sectors, and weaken employment protection legislation to promote wage devaluation and labor mobility. In this context, emigration was not an unfortunate sub product of economic recession, but the neoclassical adjustment mechanism in force.

The new post-crisis European economic governance began with the introduction in 2010 of the European Semester. The semester begins in November with the publication by the European Commission of a set of documents reflecting its analysis of the European economy accompanied by recommendations for the euro area. Following rounds of bilateral meetings with national governments, the Commission issues its Annual Reports in February, analyzing the specific situation of each country. In April, Member States present the Stability Program, with the budget plan for the next three years, and the National Reform Program, which spell out the planned structural reforms. In May, the Commission issues country-specific recommendations, which will be discussed and ratified by the European Council in June. By 15 October, national governments have to submit their draft budget plan which will be reviewed by the Commission taking into account the specific recommendations previously issued and compliance with budgetary rules. The Commission's opinion is known in November, in time to be included in the budgeting of each state.

In particular, the European Union's concern with budgetary indiscipline of member States led to the creation of a new set of regulations aimed at strengthening the Stability and Growth Pact (SGP).

The Six Pack, which came into force 2011, reinforced the preventive and corrective arms of the SGP. On the precautionary side, a rule has been created to imposes a limit on expenditure growth in line with potential GDP growth. The medium-term budgetary objective (MTO) was also set for

\footnotetext{
${ }^{10}$ See, for example, Giavazzi and Spaventa (2010), Lane (2012), Holinski et al (2010).
} 
each country, which should be in the range of $-1 \%$ of GDP to balance or surplus, after correcting the effect of the cycle and taking extraordinary measures. ${ }^{11}$ Compliance with this objective is assessed through the national stability programs and sanctions are imposed in case of deviations from the MTO. The corrective arm has been called the excessive deficit procedure, which can be triggered if the budget deficit exceeds $3 \%$ of GDP or, in the case of debt exceeding $60 \%$ of GDP, the objective of reducing it has not been met. As with the preventive arm, sanctions for noncompliance were also provided here. Finally, a macroeconomic imbalances procedure was created to apply the structure of the excessive deficit procedure to the analysis and supervision of macroeconomic, mostly current account, imbalances.

In March 2012, the Intergovernmental Treaty on Stability, Coordination and Governance in Economic and Monetary Union, also known as the Pact or Budget Treaty, was signed by several EU countries. The Pact established the "golden rule" of the budget balance, setting a minimum deficit of $0.5 \%$ of GDP for the structural deficit, which can be reduced to $1 \%$ if government debt does not exceed $60 \%$ of GDP. Countries were then obliged to inscribe this "golden rule" in their national legislation, preferably in their Constitutions. As for debt, it has been established that if it falls below $60 \%$ of GDP, the excess over this figure will have to be reduced at an average rate of $5 \%$ per year over three years. In addition, the Treaty has limited financial assistance from the European Stability Mechanism to signatory countries.

The "Two Pack", which came into force in May 2013, consists of two European regulations that complement the SGP and the Budget Treaty. The first aimed to strengthen the mechanisms for overseeing the budgetary process by establishing common schedules for all countries, and for the obligation of countries in excessive deficit procedure to present an economic partnership program with the specification of budgetary and structural reinforcements to be adopted. The second set out the rules on surveillance, financial assistance and supervision to apply to countries in crisis.

Maastricht was thus replaced by a European quasi-constitution designed to control every aspect of fiscal policy, geared exclusively to the production of surpluses. The combination of these rules, whose fulfilment is more than questionable, serves three known purposes. The first is to align fiscal policy with the monetary policy stance, ensuring that no country challenges the inflation target. The second is to ensure that there is no need for transfers between countries. The third is to limit fiscal policy action by pushing national governments towards the only possible program: liberalization. Exactly as predicted by Hayek.

\footnotetext{
${ }^{11}$ The budget balance of the general government adjusted for these effects is called the structural balance. The structural balance is not a straightforward measure of a country's fiscal situation since it cannot be observable. Its calculus implies several estimations that rely on controversial concepts, such as the potential GDP, the production function and the natural unemployment rate (NAWRU). A very comprehensive summary of these critiques can be found in Darvas (2019).
} 
The third goal - financial integration - is an ongoing process, netted around the construction of the European Banking Union and the Capital Markets Union. This process aimed not only the introduction of new forms of deregulation, under the attempt to transform continental Europe's bank-based economies into market-based economies, but also the de-nationalization of yet another set of economic instruments and policies.

Following the financial crisis, the European Commission has taken several initiatives to amend the regulatory and supervisory rules applicable to national banking systems. This rulebook, which changed prudential requirements, deposit protection schemes and created a new framework for bankruptcies, represents the foundation of the Banking Union. ${ }^{12}$

The second pillar of the Banking Union's constitution was the creation in 2013 of the Single Supervisory Mechanism, which gave the ECB direct supervisory powers over European "significant" banks. ${ }^{13}$

The third pillar, which came into force in 2016, was the creation of the Single Resolution Mechanism that centralized decisions on intervention in insolvent banks. This mechanism, which applies only to significant banks under the Single Supervisory Mechanism, is composed of a Single Resolution Board and Single Resolution Fund. The Single Resolution Board is responsible for designing and monitoring bank resolution programs for significant institutions but also for all others using the Single Resolution Fund. This decision-making process centralizes in the Board the exclusive power to decide the resolution measures to be applied to a national bank, including the internalization of losses by shareholders, creditors and depositors, as well as its liquidation. ${ }^{14}$ The Single Resolution Fund exists to finance losses arising from bank insolvencies after other mechanisms for internalization of losses by shareholders and creditors have been exhausted. They are funded by periodic contributions from significant banks, which will be initially grouped into "national compartments" and then progressively mutualised over a period of eight years. The remaining banks will continue to make their regular contributions to national resolution funds.

Finally, the European Deposit Guarantee Scheme, that would pool depositors' losses in the event of insolvency or liquidation, is the missing pillar of the European Banking Union. Until now, the

\footnotetext{
${ }^{12}$ The Capital Requirements Directive (CRD IV), supplemented by the Capital Requirements Regulation, has transposed the most stringent requirements out of the Basel III agreement applicable to the holding of capital by banks.

The Deposit Guarantee Scheme Directive (DGS) obliged Member States to set up national deposit guarantee schemes to ensure harmonized protection of bank depositors.

The Bank Recovery and Resolution Directive (BRRD), established the obligation for banks to draw up recovery plans or resolution measures in the event of financial difficulties.

${ }^{13} \mathrm{~A}$ bank is considered significant if the total value of its assets exceeds $€ 30$ billion, if its ratio of total assets to its country's gross domestic product exceeds $20 \%$ (for banks with total assets above $€ 5$ billion), or if it has significant cross-border activities.

${ }^{14}$ Avgouleas and Goodhart (2015) discuss the risks and benefits of bank bail in mechanisms.
} 
European leaders had not been able to overcome the political impasse resulting from some (core) countries' unwillingness to support losses arising from banking failures somewhere else.

Member States have therefore lost all decision-making powers over supervision and intervention in the largest national banks but remained financially responsible for the decisions of the Single Resolution Mechanism. Regardless of its incompleteness, by constraining the State's policy instruments to respond to banks in difficulties, the Banking Union exerts an influence over national banks' willingness to promote excessive credit creation or to finance expansionary fiscal policies (Cabral and Louçã, 2019). On the other hand, there is no guarantee that Council decisions on the liquidation or resolution of a national bank will correspond to the specific interests of a country or region. In fact, the practical consequence of this non-correspondence of interests has favored the concentration of banking assets in the largest European banks or international investment funds, due to the liquidation or absorption of resolved national institutions (Quaglia,2016).

Aside from the Banking Union, the European Commission published, in 2015, the Action Plan on Building the Capital Markets Union. In short, the Capital Union consists on a set of measures aimed at intensifying and integrating capital markets at the European level. Underneath this Plan is the declared idea that overall investment should be fostered by increasing and diversifying the private uses of capital markets and facilitating cross-border investments.

In general terms, the Union operates on two related dimensions of financial and capital markets. On the one hand, it intends to promote the channelling of funds from households and firms' savings into non-banking market-based entities. Apart from other measures concerning the development of retail investment products, Commission's attentions have been focused on the launching of a pan-European personal product (PEPP). Considering the prevalence of public payas-you-go pension schemes across European countries, the creation of a private market for pensions is crucial to increase the pool of assets under management by non-banking entities. On the other hand, the Capital Markets Union seeks to increase the access of households and firms to marked-based financing. This means creating or improving existing forms of direct financing, by promoting SME's private placements of debt or equity, crowdfunding or the expansion of venture capital and equity funds. But it also means the development of existing forms of financing that combine bank credit with capital marks, such as securitization or the issue of covered bonds. In other words, what is at stake is the construction of a European derivatives market.

The immense legislative and production by the European Commission under the Capital Markets Union Action Plan reflects the extent of the intended reforms. More than one decade after the Lehman Brothers' bankruptcy, the European Union recurs in the financial deregulation of capital and financial markets, throwing wide open the gates for the shadow banking system. All, of 
course, on behalf of better investment and employment prospects due to a more efficient allocation of private financial resources at the European level.

\section{CONCLUSION: CAN THE EURO BE ANYTHING BUT CRISIS?}

Before being the Euro, the common currency was already a neoliberal project. Not under this name, or with this geographical configuration, but as an ideal space for elevating market rules to a unique and definitive form of social and economic organization. For this it was necessary to erect an institutional building capable of replicating the economy, or "the market", as it is seen in the eyes of a liberal. Over the years, this process has been technically legitimized by several generations of neoclassical theories based on the principles of market efficiency and individual rationalism.

After the construction of the single market that exposed the different national economic and social structures to the pressure of external competition, came the configuration of a monetary space, which did not merely remove the technical autonomy of the national states to pursue different monetary and exchange rate policies. The currency was effectively removed from the realm of national sovereignty. Without debt monetization, budgetary autonomy, and dependent on financial markets validation, national governments have little room for maneuver, whether the goal is to defend the Welfare State or to implement any kind of industrial policy.

This conclusion should not be confused with any attempt to put forward a conspiracy theory. The Eurozone is not a macabre plan designed by a sect of obscure followers of Hayek and Robbins. It is, moreover, highly probable that most integration builders did not have contact with the proposal of the two liberal economists. What has been attempted was to demonstrate that the configuration of the Euro, with its enormous shortcomings and weaknesses, is not the result of chance or incompetence. All the main elements of this construction, as independent as they may seem from each other, have a broad theoretical support and are unified by the same neoliberal ideological glue. The European Monetary and Economic Union was the stage on which rising neoliberalism in the late 1970s could test its ideas, and shape policies, mechanisms and institutions in its own image. This is the outcome, and it is not compatible with a truly democratic project. Again, not because the Euro was created for an undemocratic purpose, but because it is the natural result of a system that is designed to impose market order on different sovereign states. This possibility was even admitted by Hayek when stating that "the abrogation of national sovereignties and the creation of an effective international order of law is a necessary complement and the logical consummation of the liberal program" (Hayek,1939). 
Should one then conclude that this is the only possible monetary union? Not necessarily. In theory, it is possible to think of another space, with other, more democratic institutions, with solidarity mechanisms, with the coordination of social and economic policies and a system of automatic transfers. Between academics, activists and politicians, hundreds of proposals have already been produced to reform the Union. The question is whether this Union, which is armored in these institutions, has some endogenous transformative potential.

For now, twenty-two years after its creation, we can only have two certainties about the Euro. The first is that it is more fragile and less able to deal with the economic and social difficulties that have been felt in Europe since the Great Recession. More so, the Euro is, by default, a source of social and economic instability. The second is that our hopes for a fairer economy must be able to see beyond it.

\section{REFERENCES}

Arestis, P., \& Sawyer, M. C. (2001). Will the Euro Bring Economic Crisis to Europe? (SSRN Scholarly Paper ID 264121). Social Science Research Network. https://papers.ssrn.com/abstract=264121

Arestis, P., \& Sawyer, M. C. (2013). Economic and monetary union macroeconomic policies: Current practices and alternatives. Palgrave Macmillan.

Avgouleas, E., \& Goodhart, C. (2015). Critical Reflections on Bank Bail-ins, Journal of Financial Regulation, 1(1), 3-29. https://doi.org/10.1093/jfr/fju009

Begg, D., Hagen, J. V., Wyplosz, C., \& Zimmermann, K. (Eds.). (1998). EMU: Prospects and Challenges for the Euro. Blackwell.

Bibow, J. (2003). Is Europe Doomed to Stagnation? An Analysis of the Current Crisis and Recommendations for Reforming Macroeconomic Policymaking in Euroland (SSRN Scholarly Paper ID 414400). Social Science Research Network. https://doi.org/10.2139/ssrn.414400

Bibow, J. (2012a). The Euro Debt Crisis and Germany's Euro Trilemma | Levy Economics Institute. The Levy Economics Institute of Bard College. http://www.levyinstitue.org/publications/the-euro-debt-crisis-and-germanys-eurotrilemma

Bibow, J. (2012b). At the Crossroads: The Euro and Its Central Bank Guardian (and Savior?)(SSRN Scholarly Paper ID 2183401). Social Science Research Network. https://doi.org/10.2139/ssrn.2183401

Blanchard, O., \& Giavazzi, F. (2002). Current Account Deficits in the Euro Area. The End of the Feldstein Horioka Puzzle? (SSRN Scholarly Paper ID 372880). Social Science Research Network. https://papers.ssrn.com/abstract $=372880$

Bongini, P. (2003). The EU Experience in Financial Services Liberalization: A Model for GATS $\begin{array}{llll}\text { Negotiations? (Research Report 2003/2). No. SUERF } & \text { Non }\end{array}$ Studies. https://www.econstor.eu/handle/10419/163456 
Buiter, W., Corsetti, G., Roubini, N., Repullo, R., \& Frankel, J. (1993). Excessive Deficits: Sense and Nonsense in the Treaty of Maastricht, Economic Policy, 8(16), 58-100. JSTOR. https://doi.org/10.2307/1344568

Buiter, W. H., \& Patel, U. R. (1992). Debt, deficits, and inflation: An application to the public finances of India, Journal of Public Economics, 47(2), 171-205.

Cabral, R., \& Louçã, F. (2019). The euro at twenty: Follies of youth? [WorkingPaper]. ISEG Departamento de Economia. https://www.repository.utl.pt/handle/10400.5/17649

Cecchetti, S. G., Mohanty, S., \& Zampolli, F. (2011). Achieving growth amid fiscal imbalances: The real effects of debt, Proceedings - Economic Policy Symposium - Jackson Hole, 145-196.

Chick, V., \& Dow, S. C. (1997). Competition and the Future of the European Banking and Financial System. In A. J. Cohen, H. Hagemann, \& J. Smithin (Eds.), Money, Financial Institutions and Macroeconomics (pp. 253-270). Springer Netherlands. https://doi.org/10.1007/978-94-011-5362-1_17

Clifton, J., Comín, F., \& Diaz, D. (2003). Privatisation in the European Union: Public Enterprises and Integration. Springer US. https://doi.org/10.1007/978-1-4757-3733-2

Coffey, P., \& Presley, J. R. (1971). European Monetary Integration. The Macmillan Press.

Darvas, Z. (2019, October 1). Why structural balances should be scrapped from EU fiscal rules, European. https://european.economicblogs.org/bruegel/2019/darvas-balances-scrappedeu-fiscal-rules

De Grauwe, P., \& Mongelli, F. P. (2005). Endogeneities of Optimum Currency Areas: What Brings Countries Sharing a Single Currency Closer Together? (SSRN Scholarly Paper ID 691864). Social Science Research Network. https://papers.ssrn.com/abstract=691864.

Delanty, G. (2016). The limits and possibilities of a European identity: A critique of cultural essentialism. Philosophy \& Social Criticism. https://doi.org/10.1177/019145379502100402

Delors, J. (1989, January 17). Bulletin of the European Communities. 1989, No Supplement 1/89. Luxembourg: Office for Official Publications of the European Communities.

Dow, S. (2016). Ontology and Theory for a Redesign of European Monetary Union, World Economic Review, 6, 1-11.

European Comission. (2008). EMU@ 10: Successes and challenges after 10 years of Economic and Monetary Union. $\operatorname{COM}(2008) 238$ final. https://eur-lex.europa.eu/legalcontent/en/ALL/?uri=CELEX\%3A52010DC2020

European Comission. (2010). EUROPE 2020 A strategy for smart, sustainable and inclusive growth. $\quad \operatorname{COM}(2010) \quad 2020$ final. https://eur-lex.europa.eu/legalcontent/en/ALL/?uri=CELEX\%3A52010DC2020

Friedman, M., \& Schwartz, A. J. (1963). Money and Business Cycles. The Review of Economics and Statistics, 45(1), 32. https://doi.org/10.2307/1927148

Giavazzi, F., \& Spaventa, L. (2010). Why the Current Account Matters in a Monetary Union: Lessons from the Financial Crisis in the Euro Area (SSRN Scholarly Paper ID 1707898). Social Science Research Network. https://papers.ssrn.com/abstract=1707898 
Goodhart, C. A. E. (1998). The two concepts of money: Implications for the analysis of optimal currency areas, European Journal of Political Economy, 14(3), 407432. https://doi.org/10.1016/S0176-2680(98)00015-9

Goodhart, C. a. E. (1999). Myths about the Lender of Last Resort, International Finance, 2(3), 339-360. https://doi.org/10.1111/1468-2362.00033

Grauwe, P. de. (2014). Economics of Monetary Union. Oxford University Press.

Hayek, F. A. (1937). Monetary Nationalism and International Stability. Longmans, Green. https://mises.org/library/monetary-nationalism-and-international-stability

Hayek, F. A. (1939). The Economic Conditions of Interstate Federalism, New Commonwealth, V(2), 131-149.

Helgadóttir, O. (2016). The Bocconi boys go to Brussels: Italian economic ideas, professional networks and European austerity, Journal of European Public Policy,23(3), 392409. https://doi.org/10.1080/13501763.2015.1106573

Heyes, J. (2011). Flexicurity, employment protection and the jobs crisis, Work, Employment and Society. https://doi.org/10.1177/0950017011419723

Heyes, J. (2013). Flexicurity in crisis: European labour market policies in a time of austerity, European Journal of Industrial Relations. https://doi.org/10.1177/0959680112474749

Holinski, N., Kool, C., \& Muysken, J. (2010). Origins of persistent macroeconomic imbalances in the Euro area (Working Paper No. 10-12). Utrecht School of Economics. https://econpapers.repec.org/paper/usetkiwps/1012.htm

Ishiyama, Y. (1975). The Theory of Optimum Currency Areas: A Survey, IMF Staff Papers, 22(2), 344-383.

Kenen, P. B. (1969). The theory of optimum currency areas: An eclectic view, Monetary Problems of the International Economy.

Krugman, P. (2014). Four observations on secular stagnation. In Secular Stagnation: Facts, Causes, and Cures. CEPR Press. https://voxeu.org/article/four-observations-secular-stagnation

Lane, P. R. (2012). The European Sovereign Debt Crisis, The Journal of Economic Perspectives, 26(3), 49-67.

McCann, D. (2010). The Political Economy of the European Union. Polity.

McKinnon, R. I. (1963). Optimum Currency Areas, The American Economic Review, 53(4), 717 725. JSTOR.

Mongelli, F. P. (2002). "New" Views on the Optimum Currency Area Theory: What is Emu Telling Us?(SSRN Scholarly Paper ID 357400). Social Science Research Network. https://papers.ssrn.com/abstract $=357400$

Mundell, R. A. (1961). A Theory of Optimum Currency Areas, The American Economic Review, 51(4), 657-665. JSTOR.

Muysken, J., Mitchell, W. F., \& van Veen, T. (Eds.). (2006). The Brussels-Frankfurt consensus: An answer to the wrong question. In Growth and Cohesion in the European Union (Mitchell, W., Muysken, J. and T. van Veen (eds.)). Edward Elgar Publishing Limited. https://cris.maastrichtuniversity.nl/en/publications/the-brussels-frankfurt-consensusan-answer-to-the-wrong-question 
Parguez, A. (1999). The Expected Failure of the European Economic and Monetary Union: A False Money against the Real Economy, Eastern Economic Journal, 25(1), 63-76.

Quaglia, L. (2019) The politics of an 'incomplete' Banking Union and its 'asymmetric' effects, Journal of European Integration, 41(8), 955-969

Robins, L. (1937). Economic Planning and International order. Macmillan.

Scharpf, F. W. (2009). The double asymmetry of European integration: Or: why the EU cannot be a social market economy (No. 09/12; MPIfG Working Paper). Max Planck Institute for the Study of Societies. https://ideas.repec.org/p/zbw/mpifgw/0912.html

Skidelsky, R. (2005). Keynes, Globalisation and the Bretton Woods Institutions in the Light of Changing Ideas about Markets, World Economics, 6(1), 15-30.

Story, J., \& Walter, I. (1997). Political Economy of Financial Integration in Europe: The Battle of the Systems. In MIT Press Books (Vol. 1). The MIT Press. https://ideas.repec.org/b/mtp/titles/0262692031.html

Summers, L. H. (2014). Reflections on the new "Secular Stagnation hypothesis" In Secular Stagnation: Facts, Causes, and Cures. CEPR Press. https://voxeu.org/article/larry-summerssecular-stagnation

Tangian, A. (2010). Not for bad weather: Flexicurity challenged by the crisis (No. 3/2010; ETUI Policy Brief. European Economic and Employment Policy). https://www.etui.org/publications/policy-briefs/european-economic-employment-andsocial-policy/not-for-bad-weather-flexicurity-challenged-by-the-crisis

Thomasberger, C. (2015). Europe at a Crossroads: Failed Ideas, Fictional Facts, and Fatal Consequences, Forum for Social Economics, 44(2), 179200. https://doi.org/10.1080/07360932.2014.951379

Economic and Monetary Union: What we have achieved and what we must do next, (2011) (testimony of JC Trichet).

Young, B. (2014). German Ordoliberalism as Agenda Setter for the Euro Crisis: Myth Trumps Reality, Journal of Contemporary European Studies, 22(3), 276287. https://doi.org/10.1080/14782804.2014.937408

Zimmermann, H. (2001). The Euro under Scrutiny: Histories and Theories of European Monetary Integration, Contemporary Huropean History, 10(2), 333341. https://doi.org/10.1017/S0960777301002090 